\title{
Possibilities of proton magnetic resonance in determination the cellulose crystallinity
}

\author{
C Yury B. Grunin, ${ }^{*+}$ and Maria S. Ivanova \\ Department of Physics. Volga State University of Technology. Lenin St., 3. Yoshkar-Ola, 424000. Mari El \\ Republic. Russia. Phone: +7 (8362) 68-68-04. E-mail: GruninYB@volgatech.net.
}

*Supervising author; ${ }^{+}$Corresponding author

Keywords: cellulose, supramolecular structure, crystallinity, nuclear magnetic resonance, spin-lattice relaxation time, spin-spin relaxation time.

\begin{abstract}
A layered model of the structural organization of macrofibrils of native cellulose, consisting of microfibrils, which include elementary fibrils, has been developed. A feature of the proposed model is the presence of slit-like pores between the crystalline elements of cellulose. It was found that, on average, each water molecule interacts with one glucose residue of the surface chains of cellulose with the formation of hydrogen bonds in the framework of monolayer adsorption. This allows to establish a correlation between the cellulose crystallinity and the capacity of the adsorption water monolayer on its active surface. Based on the condition of rapid molecular exchange between the adsorption water layers in the framework of the Bloembergen-Purcell-Pound theory, an approach is proposed for determination the capacity of water monolayer. The obtained values are consistent with the results of solving the Brunauer-Emmett-Teller equation for the adsorption isotherm of water on the active surface of cellulose. The Fourier transform of the free induction decay signal of cellulose allows to estimate its crystallinity at various moisture contents. Methods have been developed for assessing the crystallinity of different types of dry cellulose based on NMR relaxation parameters - spin-lattice relaxation time and spin-spin relaxation time. Using the method of deuteration of cellulose, the relaxation times of its crystalline regions were determined. The results of preliminary studies showed that the crystallinity of cotton cellulose is higher in comparison with the same parameter of woody types of cellulose. A comparison of the literature and the data we obtained using ${ }^{1} \mathrm{H}-$ NMR relaxation confirmed the possibility of utilizing the developed methods to solve the tasks of scientific research and conducting quality control of cellulosic materials at specialized enterprises.
\end{abstract}

\section{References}

[1] Z.A. Rogovin. Cellulose Chemistry. Moscow: Himiya. 1972. 520p. (russian)

[2] A.D. French. Glucose, not cellobiose, is the repeating unit of cellulose and why that is important. Cellulose. 2017. Vol.24. Iss.11. P.4605-4609.

[3] Y.B. Grunin [et al.] Features of the structural organization and sorption properties of cellulose. Polymer Science Series A. 2015. Vol.57. Iss.1. P.43-51.

[4] Y.B. Grunin [et al.] Supramolecular reorganizations in cellulose during hydration. Biophysics. 2015. Vol.60. No.1. P.43-52.

[5] Y.B. Grunin [et al.] Microstructure of cellulose: NMR relaxation study. Polymer Science. Series A. 2012. Vol.54. No.3. P.201-208.

[6] V.P. Nikolaev, A.A. Ageev, Y.G. Frolov. Isopiestic method of analysis. Works MKhTI them. D.I. Mendeleev. 1978. Iss.101. 84-101p. (russian)

[7] NMR analyzer «Spin Track». URL: http://www.nmr-design.com.

[8] V.I. Chizhik. Nuclear magnetic relaxation. St.Petersburg: SPbSU. 2004. 385p. (russian)

[9] A.A. Abragam. The principles of Nuclear Magnetism. Edited by G.V. Skrotskiy. Moscow: Izd. inostr. lit. 1963. 551p. (russian)

[10] Yu.B. Grunin [et al.] Dispersion Peculiarities of Crystalline Cellulose Upon its Moistening. Fibre Chemistry. 2018. Vol.49. Iss.5. P.321-326.

[11] Y. Nishiyama. Structure and properties of the cellulose microfibril. Journal of Wood Science. 2009. Vol.55. P.241-249.

[12] S.J. Gregg, K.S.W. Sing. Adsorption, Surface area and Porosity. Moscow: Mir. 1984. 2ed. 306p. (russian) 
POSSIBILITIES OF PROTON MAGNETIC RESONANCE IN DETERMINATION THE CELLULOSE ...

$116-123$

[13] I.Ya. Slonim, A.N. Lyubimov. Nuclear Magnetic Resonance in Polymers. Moscow: Chimiya.1966. 340p. (russian)

[14] N. Baiklz, L. Segal. Cellulose and cellulose derivatives: vol. 1-2. Edited by Z.A. Rogovin. Moscow: Mir. 1974. Vol.1. 500p. (russian)

[15] T.P. Shcherbakova, N.E. Kotel'nikova, Yu.V. Bykhovtsova. Comparative study of powder and microcrystalline cellulose samples of various native origins. Supramolecular structure and the chemical compound of powder samples. Khimiya Rastitel'nogo Syr'ya. 2012. No.2. P.5-14. (russian) 